\title{
Challenges and possibilities for creating genuinely intercultural higher education learning communities
}

\author{
Katri Jokikokko
}

\begin{abstract}
This article synthesises and analyses the existing research and literature that has discussed the challenges and possibilities of providing intercultural learning environments for diverse students in the context of higher education. A genuinely intercultural learning community provides equitable learning possibilities for all, is characterised by social justice, and allows all participants to feel a strong sense of belonging. Based on this review, the main challenges in creating equitable learning communities in higher education relate to institutional barriers, such as institutional racism and discrimination, monolingual higher education policies, and neoliberal educational agendas that contradict the principles of social justice. Interpersonal challenges (such as lack of intercultural competence) also exist, as do challenges related to acknowledging intercultural perspectives in curricula and pedagogy. The conditions that the existing literature suggests will create genuinely intercultural learning communities include rethinking the strategies, policies, and curricula of higher education institutions; supporting students' and staff's intercultural competences; and developing pedagogical approaches for acknowledging social justice and diverse learners. Based on the literature reviewed for this article, it is obvious that there are no easy tricks that can 'fix' the situation and create genuinely intercultural learning communities, but intercultural approaches and aspects should be widely incorporated into higher education institutions' ethics, cultures, policies, and practices.
\end{abstract}

Keywords: equity; higher education; intercultural learning community; review; social justice

Received 14 December 2020; revised version received 29 April 2021; accepted 11 August 2021. Corresponding author: Katri Jokikokko, University of Oulu, Finland (katri.jokikokko@oulu.fi).

\section{Introduction}

As higher education institutions worldwide attempt to become increasingly international and intercultural (Enders, 2004; Knight, 2011, 2014), they should 
prioritise support for all diverse learners in the best possible way and make higher education learning communities inclusive and fair for all. However, too often interculturality in higher education denotes an elitist approach to gaining intercultural experiences that emphasise global travel or profit motives for employability and intercultural capabilities to meet the demands of the labour market (Haapakoski, 2020).

This article aims at synthesising the existing scattered literature that has discussed the challenges and possibilities of providing intercultural learning environments for diverse students in the context of higher education and elaborating it from a critical perspective that acknowledges social justice and equity. Furthermore, the article aims at providing a framework that can help all actors (students, teachers, and other staff) in higher education institutions to reflect on and evaluate the current 'intercultural' situation or to develop more just policies and practices. In the discussion and conclusion section, the article presents a series of questions that can be used for such reflections.

The writing of this review began by searching for academic articles and books that were published between 2000-2021 and included the term intercultural* OR multicultural* OR international* OR decolonial* OR antiracist* OR social justice* OR multilingual* OR equality* OR equity* AND higher education* OR university* OR tertiary education* in the title, abstract, or keywords. By using these theoretically differing concepts I tried to ensure that I found as many studies as possible related to the intercultural aspects of higher education. I used EBSCO, ERIC and ARTO databases for searching the articles. Based on these searches, I found different types of texts such as journal articles, academic books, book chapters, and doctoral dissertations. I examined the abstracts of these texts to decide whether the literature is suitable for this review. After this examination, I excluded the texts that did not fit within the scope of my research questions.

Next, I analysed the chosen texts from the perspective of my research questions by identifying the possibilities and challenges related to intercultural higher education communities. I combined the texts with similar topics under subthemes (such as institutional racism and discrimination) and next I combined these sub-themes under broader main themes (such as institutional barriers). Both subthemes and main themes were specified and reformulated during the process of analysis. The main themes will be presented as results of this review.

The context of this article is 'Western' higher education. Although higher education institutions around the world are different in many ways, it has been argued that a Western model of education has dominated higher education practice worldwide suppressing local knowledge systems and dignity (Alvares, 2011; Bhambra, Gebrial, \& Nişancioğlu, 2018). Thus, the Western context of higher education in this article does not refer to geographical area but more to Western 
hegemony in higher education systems around the world. Another central assumption of this article is that all higher education communities are diverse and thus 'intercultural' is considering differences related not only to nationality and language but also to gender and sexuality, socioeconomic background, religions, worldviews, and so on. So, it is important to highlight that creating intercultural learning communities does not only mean organising education for 'international' students, but that creating such communities is essential for all. Nieto (2000) has argued that including critical reflection of intercultural issues in the curriculum and educational practices is even more important for those who are privileged in relation to ethnicity, gender, race, sexuality, and socioeconomic background.

The present article will first conceptualise a 'genuinely intercultural learning community in higher education' and then present the results of the review. It will focus on the challenges of creating genuinely intercultural learning communities in higher education by discussing the institutional, interpersonal, and pedagogical problems that earlier studies have identified in relation to providing fair learning possibilities for all in the context of higher education. It will then continue by discussing the conditions that have been presented in the literature as possible solutions to these problems.

\section{Defining and conceptualising a genuinely intercultural higher education community}

Especially in the European context, the word 'intercultural' has largely replaced other similar terms such as 'multicultural' (Coulby, 2006). It has been argued that 'intercultural' is a term that suggests actual interaction among people and emphasises mutual learning (e.g., Räsänen, 2007). However, the term 'intercultural' also warrants criticism as it may be used in an essentialist way to refer to interaction between us and 'different' (often foreign) others (Dervin, 2015). The notion of 'culture' in 'intercultural' can be especially problematic. If we put culture at the centre of interaction, we may ignore the notion of intersectionality, which implies that many identities are in interplay in social situations, not just 'culture' (Banks, 2008; Dervin, 2015). Furthermore, historical realities of intercultural interactions, such as slave trade, imperialism, racism, genocide, and conquest, often seem to be ignored in the studies and literature that focus on intercultural relations, competences, and communication (Hoskins \& Sallah, 2011). Intercultural relations are often not equal.

In the context of higher education, the term 'intercultural' can also be conceived in different ways. It may describe projects and approaches that 'celebrate diversity' (Guo \& Guo, 2017). Intercultural education can be understood to be 
intended for international students seeking to adapt to their host countries and to benefit from the knowledge and wisdom that their host universities offer (Ryan, 2013). Furthermore, interculturalism can denote an elitist approach to gaining intercultural experiences that emphasise global travel or profit motives for employability and intercultural capabilities to meet the demands of the labour market (Haapakoski, 2020). All the above-mentioned approaches to interculturalism in the context of higher education ignore the social justice and equity aspects.

Despite the critics, I have chosen the term 'intercultural' for this study because I see mutual and dialogical learning and interaction as important in intercultural contexts. However, it is important to emphasise that especially in the context of education the term 'intercultural' needs to be accompanied by a deep commitment to social justice and equal access to educational resources (cf., Nieto, 2017). In this article, 'genuinely intercultural' refers to equity between diverse participants, fair learning resources, and inclusion of all. Furthermore, in the context of higher education, it also means acknowledging diversity, social justice, and equity in the contents and methods of teaching.

In this article, the intercultural learning community refers to any group of diverse people (with multiple identities) learning together and from each other. Diversity is understood from the intersectional perspective: different and multiple identities and characteristics (such as class, gender, and race) 'intersect' with one another and overlap in various intercultural situations in complex ways (e.g., Cho, Crenshaw, \& McCall, 2013). Even if the terms such as 'international students' and 'host students' are used in this article when this division is made in existing literature, it is clear that both groups are extremely heterogenous. This article does not focus especially on 'international students' but on how higher education institutions may become more inclusive and intercultural learning environments for all students.

Higher education institutions in their entirety can be considered to be learning communities that encompass many diverse smaller learning communities. A learning community's purpose is to engage in and promote activities and interaction that facilitate equitable and meaningful learning experiences and support for all its members (cf., Lave \& Wenger, 1991). Strong social communities have been demonstrated to be valuable for personal welfare and well-being and for academic success (Rienties et al., 2012). According to Vasquez (2005), community, which concerns relationships, forms the basis of human existence, bringing individuals together in united awareness and feeling. Relationships occur through conversation, dialogue, and participation (Vasquez, 2005).

For genuinely intercultural learning communities, equity between participants and inclusivity become the central characteristics (e.g., Pettigrew \& 
Tropp, 2008). However, it is important to acknowledge that power issues are inevitably present in any learning community. Arguably, no perfectly fair or safe learning communities exist, as the conditions of power and privilege always operate within them (Boler \& Zembylas, 2003). However, Boler and Zembylas (2003) also emphasise that despite these power imbalances, it is possible to foster a degree of safety and equality (including commitment, responsibility, and compassion from students and teachers alike), even under discomforting conditions. It is not only interpersonal relationships that must be considered when analysing intercultural learning communities, but institutional structures, policies, cultures, and practices also play a significant role and are intertwined with human relationships in complex ways.

\section{Challenges for creating genuinely intercultural higher education learning communities}

\section{Institutional barriers}

As mentioned above, for a learning community to be truly intercultural, all students must be provided with equitable conditions and support for learning. However, the existing literature reveals many systemic barriers in higher education that challenge this requirement.

Based on the previous research, the educational norms, (implicit) rules, and traditions (such as 'proper' intellectual standards, ways of knowing, communicating, and behaving) of the (host) institution can be confusing and even discriminating especially for international students and may lead to feelings of inferiority (Turner, 2009). Higher education institutions often prioritise dominant host ideas regarding intellectual norms and group dynamics that can be exclusionary for some students (Turner, 2009). However, it is not only international students who may suffer from these norms and face discrimination in a higher education institution: studies have shown that higher education institutions in many countries fail to provide their domestic students from across diverse minority groups (e.g., ethnicity, gender and sexual orientation, specific learning needs, etc.) with relevant and inclusive learning experiences (Bourke, 2010; Gilardi \& Guglielmetti, 2011), thereby denying them equitable academic and employability outcomes (Berry \& Loke, 2011; Stevenson, 2012; Turner, 2013).

As Boyer and Davis (2013) state, institutional racism persists on our campuses (see also Long, 2016). Allison et al. (2020) remind us that white people dominate staff positions in higher education, and racist mindsets, whether conscious or unconscious, are prominent both among students and staff. This manifests as white dominance and supremacy, making higher education environments unwelcoming and intolerant towards students of colour who often feel that they do 
not belong (Allison et al., 2020). The same may be said of faculty of colour, who may encounter frequent and disparaging issues such as salary disparities, workplace discrimination with respect to hiring, and denial of tenure and promotion (Boyer \& Davis, 2013). It has further been observed that different 'diversity initiatives' in higher education have focused on merely changing individuals rather than dismantling the structural inequalities that perpetuate systemic racism in higher education institutions (Case, 2007). The initiatives focusing on individuals may strengthen the deficit mindset, which frames students of colour as 'lacking some of the academic and cultural resources necessary to succeed in what is presumed to be a fair and open society' (Smit, 2012, p. 369) and constructs 'images of people of color as outsiders, at-risk victims, commodities, and change agents' (Iverson, 2007, p. 586).

Systemic discrimination in educational institutions affects gender and sexual minorities in particular (Alanko, 2014; Tereskinas, 2010). For example, heteronormative and sexualised modes of expression and representation as well the physical spaces of educational institutions can be exclusionary and distressing for some students (Formby, 2017). A strong gender bias is still evident in many fields of higher education, such as engineering, technology, and maths (Schiebinger, 2008). Women's presence in the highest academic and decision-making positions in scientific institutions and universities is also strikingly low, despite the fact that most students in higher education in many countries are women (Müller et al., 2011).

The language policies of higher education can become an institutional barrier for equitable and inclusive learning for some students. For example, the expansion of English-medium teaching in higher education in non-English speaking countries has been rapid especially in Europe and Asia (Evans \& Morrison, 2011). English is also increasingly more the only language of 'highquality' academic research and literature since many academic publishers do not accept any other languages, making English the measure of academic capability (King Choi, 2010). Thus, the dominance of English language not only concerns 'international' programmes, but also 'domestic' programmes in higher education. English hegemony in higher education can easily lead to situations in which native and fluent English speakers are given undue advantages, while other students (and staff members) are positioned as linguistically and culturally deficient (Lee, 2013; Preece \& Martin, 2010). This deficit orientation may reinforce cultural essentialism and structural disadvantage (Young, Handford, \& Schartner, 2017). Furthermore, higher education institutions usually adhere to monolingual language policies, which can be restrictive with respect to learning and teaching. Multilingual students and staff are often perceived as problems that must be fixed rather than as a resource (Skutnab-Kangas et al., 2009). As van der Walt (2013) mentions, education's 
prioritisation of one particular language (and often very specific forms and registers of that language) constitutes a violation of social justice and impedes effective learning and access to knowledge.

A complex relationship exists between language and identity (e.g., Bucholtz $\&$ Hall, 2005). Whether language is understood as an identity or more as a learning tool, it can enable or prevent the development of an academic (even preprofessional) identity, for example, where students are or are not proficient in the language of learning and teaching (Mazak, 2017). When students are discouraged from using the languages at their disposal for learning, either actively or merely by ignoring other languages, they are deprived of practices and tools that they can access and mobilise with relative ease (Mazak, 2017).

Finally, the prevalence of neoliberal philosophy and practices in higher education can be considered a systemic, institutional barrier for creating a genuinely intercultural learning community. The neoliberal agenda narrows down the meaning of interculturalism and internationalisation to emphasise profit motives for employability and capabilities to meet the demands of the labour market at the expense of education for social justice and equity: capabilities to contribute to the development of a more equitable global higher education and society (Haapakoski, 2020; Sperduti, 2017). From an intercultural and diversity perspective, the neoliberal agenda favours projects and programmes (especially related to mobility) designed to train small numbers of students as future international affairs specialists (Sperduti, 2017), completely ignoring the need to prepare all graduates to work in an interconnected world regardless of their profession. The neoliberal focus on 'impacts' or 'standards' also inevitably diminishes the significance of diversity (Jokikokko \& Uitto, 2017). Market-driven educational policies diminish the equality of opportunities (including access) in higher education for different racial, ethnic, socio-economic, religious, or gender groupings (Lazin, Evans, \& Jayaram, 2010). Neoliberal education policy emphasising competition and economics has also been connected to significant increases in students' mental health problems (Bambra \& Schrecker, 2015). Students from lower socioeconomic backgrounds may be particularly at risk of experiencing mental illness, as high tuition fees, debt, financial insecurity, and low standards of living are strongly associated with depression and anxiety (Bambra \& Schrecker, 2015).

\section{Interpersonal barriers}

In addition to institutional barriers, previous research has also acknowledged problems related to interpersonal relationships that challenge the idea of a genuinely intercultural learning community in higher education. Interpersonal relationships are often intertwined with the previously described institutional barriers in complex ways. 
Interpersonal relationships are instrumental in building genuine intercultural learning communities, and meaningful and equality-based interpersonal relationships reportedly reduce stress and improve self-esteem and psychological well-being in general (Spencer-Oatey \& Dauber, 2019). Furthermore, a sense of belonging and integration may also be associated with improved academic achievement (Rienties et al., 2012). Stress and loneliness have been recognised as particularly problematic for international students, but are increasingly affecting all students (Sawir et al., 2008).

Research has shown that especially international students can encounter discrimination based on national citizenship and race (as discussed in the previous section) and that domestic students are often unwilling to socially or academically engage with international students (Harvey, McCormick, \& Vanden, 2019). It has been argued that the majority of domestic students appear resistant to finding their 'international' or 'multicultural' course-mates sufficiently interesting to make the efforts needed to interact with them or learn from them (Fozdar \& Volet, 2016). Students seem to be reluctant to move beyond the comforts of their ingroups, their established communities of similitude (Bourke, 2010). Furthermore, Bourke (2010) states that within the internationalisation of higher education policies, the greatest focus appears to be on the potential learning gain for domestic students: the benefits of diversity are more generally focused on the experiences of mainstream - often white-students and their experiences with minority group students and any subsequent impact on leaning, which gives so-called multicultural students an instrumental value (Bourke, 2010). Some students in minority groups (such as students of colour) have expressed discontent with the expectation that they should be 'the' authority on matters related to their particular race or ethnicity, as it inevitably positions them as others (Bourke, 2010). Taking the above discussions and existing research into account, it is unsurprising that international students as well as students of colour and students belonging to different minorities may experience feelings of isolation, frustration, and despair in higher education contexts (Bodycott, Mak, \& Ramburut, 2014).

Both higher education students and staff may lack the intercultural competences required to create and support equitable intercultural learning communities. Higher education teachers may lack competences to adapt their teaching approaches to support culturally diverse learners or include intercultural contents in their teaching (Renfors, 2019). Students and teachers may have a narrow and problematic understanding of intercultural competence, which is still often understood as the ability to understand cultural differences, communicate effectively in cross-cultural situations, and to behave appropriately in a variety of cultural contexts (e.g., Bennett \& Bennett, 2004). This kind of approach to intercultural competence can be ethnocentric and essentialist, and lack reflexivity 
(Dervin \& Gross, 2016). From the perspective of social justice and equity, intercultural competence (in education) should focus on recognising, critically reflecting on, and addressing unequal attitudes, procedures, and practices (Jokikokko, 2016). Furthermore, intercultural competence should help us to question and reflect on our own assumptions and beliefs about the world and the other (Dervin \& Gross, 2016). Both students and staff may have limited understanding of specific intersecting structural inequalities (such as ethnicity plus sexuality plus gender plus language), which may advantage or disadvantage individual students in a learning community (Nichols \& Stahl, 2019). If these inequalities are not recognised or addressed, the provision of equitable and empowering learning experiences for certain student groups becomes increasingly difficult.

Furthermore, students (particularly white middle-class students) may be resistant to discussing and reflecting on the issues of power, social justice, privilege, and race, which are topics that should not be avoided if the aim is to support students' intercultural competence and, through that, the creation of an intercultural learning community (Taylor, 2011). Staff can also question the relevance of discussing and reflecting on these topics to their given fields; a common belief that intercultural issues do not belong to 'me' but to 'someone else' appears to be widespread in higher education (Räsänen, Jokikokko, \& Lampinen, 2018).

\section{Lack of intercultural perspectives in the curriculum and pedagogy}

Central to genuinely intercultural learning communities is acknowledgement of students' diverse backgrounds, skills, and needs in teaching and learning as well as integrating social justice issues in the contents and methods of teaching. Recognition of prior (cultural) understandings is known to facilitate learning and comprehension of new concepts and contents (Owens, 2011). The provision of fair learning possibilities for all students requires that students be acknowledged as unique individuals with different skills and knowledge. However, existing research clearly shows that students' (cultural) backgrounds, prior knowledge, and skills are not generally recognised in higher education curricula or pedagogy (Chen \& Bennett, 2012).

Curricula in higher education usually give precedence to Western cultural views, methods, and contents (Bell, 2008; Connell, Collyer, Maia, \& Morrell, 2016; Fahey \& Kenway, 2006). Western views, together with neoliberal ideologies based on economic standards, dominate over others, and seem to be granted epistemological privilege that facilitates the suppression of other knowledge systems by defining what knowledge is and who is qualified to understand and apply it (de Sousa Santos, 2007; Haapakoski, 2020). Different modes of knowing typically go unacknowledged or are framed through 'abyssal thinking' as non- 
scientific or unrealistic, and alternative cultural academic expressions are not considered to be legitimate ways to complete studies (de Sousa Santos, 2007; Fahey $\&$ Kenway, 2006). The prevalence of Western views in higher education also highlights the tensions between the local and the global and between the less developed South and the more developed North in today's world. These tensions (including the problematisation of how we think and teach about development, progress, others, poverty, coloniality, and so on) are frequently overlooked but are nonetheless extremely important if we genuinely want to internationalise and 'interculturalise' the curriculum (e.g., Alasuutari, 2015).

Johnson and Onwuegbuzie (2004) have identified dominant pedagogical practices in higher education that also reflect the previously described Western neoliberal educational ideology and thus form a barrier to the development of an intercultural learning community that requires the acknowledgement of different learning styles and approaches. The dominant practices include emotional detachment, rhetorical neutrality, formal writing styles, technical terminology, and time- and context-free generalisations. Instruction in these abilities, combined with continuous assessment requirements, provides little or no time to either discuss prior learning or current opinions, or to actually become involved in social issues individually, in groups, or as a class (Johnson \& Onwuegbuzie, 2004). The abovementioned pedagogical practices offer few opportunities for reflection on personal experience and expression of personal views, including on unit content, despite the fact that such opportunities would be beneficial in terms of intercultural learning and learning from others (Owens, 2011).

\section{Conditions for creating genuinely intercultural learning communities in higher education}

\section{Restructuring policies, strategies, and curricula}

Mission statements and strategies in higher education institutions worldwide emphasise internationalisation and the importance of intercultural competence, but these terms can be narrowly understood or poorly integrated into higher education curricula (e.g., van Gaalen, 2010). Thus, higher education institutions should engage in critical examination of their own functions, including whether they serve all students equally (Haapakoski, 2020). A broader higher education level strategy and long-term planning related to interculturality, rather than a series of isolated and ad hoc activities, could help to introduce more sustainable changes (Brewer \& Leask, 2012). The implementation of such a strategy would ensure that the actors in higher education institutions are given opportunities to reflect on what the 
intercultural aspects of internationalisation mean for different faculties, different disciplines, teaching, and students' learning (Brewer \& Leask, 2012).

It is obviously not enough that intercultural aspects of higher education would be emphasised in the strategies and mission statements of higher education, but these statements should result in curriculum planning and enactment (van Gaalen, 2010). Faculty members should be given the space and time to discuss and plan how intercultural aspects may be meaningfully incorporated into the curriculum. Students from different cultural, ethnic, and socioeconomic backgrounds should also be included in these discussions (cf., Brewer \& Leask, 2021) as the curriculum development process should not be the work of an individual or a single office or group but rather should be a collaborative and iterative process involving faculty, students, administrators, and institutional leaders (Deardorff, De Wit, \& Heyel, 2012). Extensive research is available to support the development of learning contents and approaches that respond to the institutions' missions (Deardorff, De Wit, \& Heyel, 2012).

Rather than exclusively emphasising Western ontologies, epistemologies, and ideologies in teaching contents and methods, different ways of thinking and knowing, such as indigenous knowledge, anti-colonial knowledge, and southern critical engagement with northern theories, should be more visible in higher education curricula as legitimate academic resources (Connell, 2007). The integration of alternative knowledge, with a preference for student knowledge, can provide for greater awareness of the constructed nature of power positions and return ownership of agency to subverted actors (Takayama et al., 2016).

Monolingual language policies in higher education should be reconsidered to support the creation of genuinely intercultural learning communities. It has been suggested that different languages could be appreciated and used more flexibly also in higher education and that multilingual practices, such as translanguaging, should be encouraged more. Translanguaging has been suggested as a practice that may potentially disrupt monolingual ideologies and provide more meaningful and inclusive instruction, especially to linguistic minorities (Mazak, 2017). It has been argued that translanguaging is a naturally occurring phenomenon for multilingual students (Canagarajah, 2011). According to Mazak (2017), translanguaging in the context of higher education could mean that both students and staff use their entire linguistic repertoire and semiotic resources strategically to teach and learn and acknowledge the consequences that linguistic performance can have for identity. Translanguaging is not limited to what is known as 'code-switching' but rather seeks to include any practices that draw on an individual's linguistic and semiotic repertoires (including reading in one language and discussing the reading in another language). Translanguaging is a new field; its set of practices is still being researched and described, and its full potential has yet to be fully acknowledged 
(Mazak, 2017). Translanguaging is usually discussed in the context of 'international' or 'bilingual/multilingual' higher education communities, but the definitions of bilingualism or multilingualism are controversial. According to the broadest definition, everyone is bilingual: all know at least a few words in languages other than the maternal variety (Edwards, 2006). Edwards (2006) goes as far as stating that monolingualism is an aberration and a disease that should be cured.

Recruitment strategies in higher education also deserve critical reflection and change. Recruitment of staff from diverse national, cultural, racial, and linguistic backgrounds could help to change monocultural and monolingual practices in higher education (Brewer \& Cunningham, 2010). On the other hand, as Allison et al. (2020) point out, people of colour (and other discriminated groups) should not be burdened with yet further responsibility for fixing a system that has historically disadvantaged them. Thus, the diversification of staff is not only a recruitment issue but requires the acknowledgement and removal of systemic barriers to higher education (Allison et al., 2020). Allison et al. (2020) highlight the need for critical consciousness, particularly among those in dominant positions at higher educational institutions, and the sharing of power across racial lines for the equity and empowerment of all campus community members.

\section{Supporting the intercultural competence of staff and students}

To renew the strategies, curricula, and practices, higher education students and staff should be provided with possibilities for personal intercultural learning, particularly self-reflection. Faculty members are key to implementing intercultural aspects in practice (Leask, 2009). They should be provided with support for critical reflection on their own values, practices, beliefs, and ideals in relation to diversity and social justice in the context of higher education (Jokikokko \& Uitto, 2017). Intercultural theorists (e.g., Jokikokko \& Uitto, 2017; Zembylas, 2012) have long argued that intercultural learning starts with leaving the comfort zone, thinking critically about oneself and others, and engaging beyond one's immediate circle. For both staff and students, it is of the utmost importance that they become aware of their implicit biases in relation to diversity and different groups and identities. It must be acknowledged that misinformation has been disseminated about many groups, even our own (Ferber, Herrera, \& Samuels, 2007). Reflection on one's emotions and emotional states is important in intercultural learning (Jokikokko \& Uitto, 2017). Ferber et al. (2007) points out that our cultures teach us how we should feel about various groups (such as people with disabilities or transgender individuals). For this reason, it is important to critically reflect on our own feelings that emerge when we consider the different groups that we encounter as higher education staff and students. 
To be able to recognise and address the systemic nature of oppression and racism, students, faculty, and staff should be more thoroughly educated about institutional and systemic inequalities and racism (Allison et al., 2020). Allison et al. (2020) highlight that to be fully aware of systemic racism, critical self-reflection is required on the systematic privilege inherent in whiteness and the development of an awareness of how whiteness shapes both conscious and unconscious thinking processes in relation to race.

Long-term (compulsory) in-service training and mentoring programmes may help to strengthen higher education staff's competence in the field of intercultural issues. Seminars or workshops aimed at enabling faculty to 're-vision' what they know (Winston, 2001, p. 69), gain new content knowledge, and 'test new pedagogical approaches encouraging experiential and intercultural learning' (Brewer \& Cunningham, 2010, p. 215) are needed. Faculty members themselves could also be encouraged to gain intercultural experiences (e.g., teaching exchanges in different institutions and academic cultures) and to be open to learning from their diverse students (Peterson, 2000). Teaching exchanges should not merely amount to elitist 'academic tourism', as intercultural learning necessitates interpersonal encounters with others from diverse backgrounds and possibilities to challenge one's own beliefs, worldview, and values (e.g., Prechtl \& Davidson Lund, 2009).

Faculty members could also learn from those colleagues who have successfully incorporated social justice aspects in their teaching: they could be invited and provided with resources to lead or collaborate on the establishment of an interdisciplinary practitioners' community to support course design and socially just practices in higher education (Woodruff, Martin, \& O’Brien, 2015).

\section{Pedagogical means for acknowledging diverse learners}

Intercultural pedagogy aims at utilising student diversity and the comparative perspectives that it offers as a positive stimulus for learning. The exploration of a subject among students of diverse ethnicities, genders, nationalities, socioeconomic backgrounds, and so on creates opportunities for engagement with alternative perspectives and can develop critical thinking, civic mindedness, openness, and other learning gains (Cole \& Zhou, 2014; Denson \& Bowman, 2013). Intercultural education embraces a multiplicity of perspectives, of imagined 'actualities', and through such acceptance of difference affords each individual respectful and equal recognition, which is imperative for students to feel that their cultural identities are acknowledged (Allen, 2018, p. 267). As Liddicoat et al. (2003) observe, interculturality is dependent on interactive dialogue, whereby different opinions can be respectfully shared and discussed in a safe environment (p. 43).

Although a wholly safe and just learning community may be impossible to attain (Zembylas \& McGlynn, 2012), it is important to aim for learning 
environments that are as supportive, safe, and just as possible, in which staff and students can feel free to make their representations, negotiate meanings, and move forward their state of knowledge. McKinley et al. (2019) refer to comfortable intercultural spaces when referring to a learning environment that acknowledges diverse learners. As McKinley et al. (2019) point out, a 'comfortable' space here is not one in which people can feel relaxed, as that does not sit well with the dynamic nature of intercultural interactions. However, the ability to negotiate the conflict of values and interests - a necessary catalyst for creativity and development - develops more effectively in a safe space where participants can feel free to negotiate and address the conflict (Whitchurch, 2008). It has been suggested that higher education staff should also accept the tensions and conflicts that they themselves experience as potentially valuable learning opportunities for selfreflection, and that they should embrace rather than avoid the tensions they experience as a means of informing their practices and contributing to the establishment of a comfortable third space (McKinley et al., 2019).

In a genuinely intercultural learning community, people believe that they have responsibilities towards one another, and mutuality and sharing represent the recognition of our ultimate interdependence, which is the ultimate substance of social peace (Graeber, 2011). Social harmony and cohesion are often regarded as core goals for communities. However, Gorski (2008) reminds us that, too often, intercultural educators conflate conflict resolution and peace with justice. In the absence of equity and social justice, peace and conflict resolution merely reify the existing social order. Intercultural education should not become yet another vehicle for the maintenance of order through conflict resolution while injustices are left unresolved (Gorski, 2008).

Different ways of knowing and divergent learning habits and dispositions should be supported in the interest of creating genuinely intercultural higher education learning communities (Biggs, 2001; Doherty \& Singh, 2005). Furthermore, not only cognitive but also affective and social aspects of learning should be afforded greater acknowledgement (Turner, 2009). A more pluralistic ontology that rejects binarism would facilitate the adoption of a perspective that is open to multiplicity and to investigating how various cultural discourses intersect; multiplicity can occur in relation to ways of voicing, ways of seeing, ways of acting, and ways of knowing (Allen, 2018). It can mean the utilisation of different language styles and multilingualism, creating greater space for the expression of personal and alternative views, integrating different learning modes, and promoting student agency by disseminating clear information regarding power positions (Allen, 2018). The above-described approaches can reinforce each student's sense of belonging within diversified contexts, thereby promoting interculturality and social justice (Allen, 2018). 
Higher education staff should be encouraged to confront 'difficult' topics (such as racism and privilege) with their students, even if discussing these topics is difficult for students and may cause resistance, fears, and discomfort (Taylor, 2011). Discomforting emotions play a constitutive role in challenging dominant beliefs, normative practices, and social habits that sustain social inequities and in creating possibilities for individual and social transformation (Jokikokko \& Uitto, 2017; Zembylas 2012).

It has also been suggested that 'listening' and 'slowness' (such as different art activities) should be integrated into higher education curricula to support students' abilities to learn from themselves and each other and to resist narrow neoliberal educational agendas (Goldberg, 2001). As Goldberg (2001) argues, artistic activities, personal expression, and creativity immediately reject Eurocentric and neoliberal influences on education, the emphasis on market gain, and testing on a final outcome, which depletes teaching's social dimension and diminishes the space for relationships of trust between teacher and student.

As noted above, students are often reluctant to venture beyond the comforts of their ingroups and their established communities of similitude. Thus, they also require support from staff to form intercultural relationships (Kazuhiro, Volet, \& Whitsed, 2019). For example, teachers can aim to form groups for group work that are as diverse as possible to facilitate feelings of inclusion, intercultural interaction, and learning from others; however, these groups should be carefully instructed and followed to monitor potentially unequal power relations, particularly if the group work is assessed and students' academic success is bound to the efforts of others (Kazuhiro et al., 2019). It should also be acknowledged that interpersonal relationships alone are insufficient to dismantle systemic racism and privilege (Sullivan, 2014).

\section{Discussion and conclusion}

This article has elaborated on the challenges and conditions of genuinely intercultural learning communities based on a review of relatively recent existing studies. Literature considered in this article is published in English (with the exception of a few Finnish sources) which definitely is a limitation. Non-English literature could have added some divergent and more nuanced views to discuss the topic of this article.

A genuinely intercultural learning community is a learning community that is characterised by socially just learning possibilities; it is a community in which all participants feel a strong sense of belonging and where intercultural aspects are integrated into curriculum and educational practices in a meaningful way. Based on 
a broad and intersectional approach to diversity, this article argues that all higher education institutions, whether they consider themselves 'international' or not, should aim at creating genuinely intercultural learning communities and acknowledge their roles in supporting different learners and promoting social justice. Based on the research reviewed for this article, the main challenges of creating socially just intercultural learning communities relate to institutional barriers, such as institutional racism and discrimination, monolingual higher education policies, and neoliberal educational agendas that contradict the principles of social justice. Interpersonal challenges (such as lack of intercultural competence) also exist in addition to challenges associated with the acknowledgement of intercultural perspectives in curricula and pedagogy. The conditions that earlier research has recommended for creating genuinely intercultural learning communities include rethinking higher education institutions' strategies and policies, supporting students' and staff's intercultural competences, and developing pedagogical approaches that acknowledge social justice and diverse learners. Based on the literature reviewed for this article, it is clear that to create genuinely intercultural learning communities, there are no easy tricks to 'fix' the situation, but intercultural approaches and aspects should be widely addressed in the ethos, culture, policies, and practices of higher education institutions.

Thus, based on the analysis of the previous literature and research discussed in this article, genuinely intercultural higher education learning communities may seem to be an unrealistic utopia, as it would require holistic changes to policies and practices of higher education. However, as a considerable amount of research is available about the challenges and conditions, there is also a good basis for planning and implementing the change. It is important to acknowledge that intercultural and social justice issues are directly connected not only to people's wellbeing and futures but also to sustainability and the planet's future. As Busch (2016) states, fair and constructive intercultural relations can be seen as a very basic pre-condition for the sustainable development of any other social fields. Conflicts in intercultural relations on a global scale may have serious harmful consequences to political, economic, and ecological sustainable development (Busch, 2016). It has been argued that the survival of humankind depends on its ability to achieve greater social equity and economic security in ways that reflect the biophysical reality (Rees, 2014, p. 193). Higher education institutions should acknowledge their responsibility in supporting our planet to sustain future generations by focusing much more on addressing the injustices and growing inequalities that are evident also in the structures and practices of higher education.

Drawing on the literature discussed in this article, I have devised several questions that we could ask ourselves as actors in higher education. These questions 
could help to reflect on and evaluate the current 'intercultural' situation in the institution and to develop fairer and socially just practices in higher education.

Questions related to evaluating institutional attitudes, structures, and policies:

- How are interculturality and internationalism understood in my institution?

- How is student diversity understood in my institution? Is intersectionality (and what identities produce advantage and disadvantage) acknowledged?

- How do social justice and equity guide the policies and practices of my institution?

- What kind of norms and rules (also implicit and non-written) are there in my institution that can be unjust for some students/staff members?

- What kind of practices in my institution may be unjust for some students/staff members?

- How do systemic racism and discrimination operate in my own work/in my institution?

- How are discrimination and racism discussed and addressed in my institution?

- What kind of language policy is implemented at my institution? How is multilingualism supported in my institution?

Questions related to personal values, interpersonal relations, and pedagogical thinking and action:

- How do I understand the concepts of social justice, diversity, and interculturality?

- What kind of assumptions and beliefs do I have about 'others'?

- Whose interests am I serving in my work?

- How do my own values, beliefs, and attitudes affect my work?

- How do social justice and equity guide my work?

- How (much) do I discuss the issues related to social justice in my work/How can I include these contents into my work?

- How can I create safe spaces to also discuss controversial issues?

- How can I support multilingualism in my work?

- How diverse are the knowledge bases and learning and evaluation methods in my work?

- What can I do differently in my work to better support diverse students/staff members and social justice?

- What can I do differently to change unequal practices in my work/in my institution? 
Journal of Praxis in Higher Education, Special Issue, Vol. 3, No. 2 (2021)

\section{Author biography}

Katri Jokikokko, PhD., Docent, is a senior university lecturer in the Faculty of Education, University of Oulu. Her research focuses on intercultural learning, competence, and pedagogy, and especially the role of emotions in intercultural learning processes. She is also interested in teachers' professional learning (especially induction phase) and has published numerous articles on these areas. She has been involved in developing international programmes in the Faculty of Education, University of Oulu for more than 15 years. 


\section{References}

Alanko, K. (2014). Mitä kuuluu sateenkaarinuorille Suomessa?[How is rainbow youth doing in Finland?] Helsinki: Nuorisotutkimusverkosto/ Nuorisotutkimusseura \& Seta.

Alasuutari, H. (2015). Towards more ethical engagements in North-South Education section partnerships. (Doctoral Dissertation. University of Oulu, Faculty of Education). Tampere: Juvenes Print. Retrieved from: http://jultika.oulu.fi/files/isbn9789526210568.pdf

Allen, S. (2018). Creative diversity: Promoting interculturality in Australian pathways to higher education. Journal of International Students, 8(1), 251273. https://10.5281/zenodo.1134301

Allison N., Hill, R., Risdon, S., \& Jun, A. (2020). Antiracism in higher education: A model for change. Race and Pedagogy Journal, 4(3). Retrieved from: https://soundideas.pugetsound.edu/cgi/viewcontent.cgi?article=1071\&cont ext=rpj

Alvares, C. (2011). Alternatives to current (ancient) university pedagogy. In C. Alvares, C., \& S. S. Faruqi (Eds.), Decolonising the university: The emerging for non-eurocentric paradigm (pp. 298-307). Penang: Penerbit Universiti Sains Malaysia.

Bambra, C., \& Schrecker, T. (2015). How politics makes us sick: Neoliberal epidemics. New York: Palgrave Macmillan.

Banks, J. (2008). An introduction to multicultural education. Washington, DC: Pearson, Allyn/Bacon.

Bell, M. (2008). Beyond the supermarket: Lost opportunities in summer study abroad for Singapore sojourners in Australia. International Journal of AsiaPacific Studies, 4(1), 61-78.

Bennett, J. M., \& Bennett, M. J. (2004). Developing intercultural sensitivity: An integrative approach to global and domestic diversity. In D. R. Landis (Eds.), Handbook of intercultural training (pp. 147-166). Thousand Oaks: SAGE. https://doi.org/10.4135/9781452231129.n6

Berry, J., \& Loke, G. (2011). Improving the degree attainment of Black and minority ethnic students. London: Equality Challenge Unit/Higher Education Academy

Bhambra, G. K., Gebrial, D., \& Nişancıoğlu, K. (2018). Introduction. Decolonising the university? In G. K. Bhambra, D. Gebrial \& K. Nişancıoğlu (Eds), Decolonising the university (pp. 1-15). London: Pluto Press.

Biggs, J. (2001). Enhancing learning: A matter of style or approach? In R. Sternberg \& L. F. Zhang (Eds.), Perspectives on thinking, learning and cognitive styles (pp. 73-102). Mahwah, NJ: Lawrence Erlbaum. 
Bodycott, P., Mak, A. S., \& Ramburut, B. (2014). Utilising an internationalised curriculum to enhance students' intercultural interaction, engagement and adaptation. Asia-Pacific Educational Research, 23(3), 635-643. https://doi.org/10.1007/s40299-013-0136-3

Boler, M., \& Zembylas, M. (2003). Discomforting truths: The emotional terrain of understanding difference. In P. Trifonas (Ed.), Pedagogies of difference: Rethinking education for social change. New York: RoutledgeFalmer.

Bourke, B. (2010). Experiences of Black students in multiple cultural spaces at a predominantly White institution. Journal of Diversity in Higher Education, 3(2), 126-135.

Boyer. J., \& Davis, P. G. (2013). Social justice issues and racism in the college classroom: Perspectives from different voices. WA, UK: Emerald Group Publishing Limited.

Brewer, E., \& Cunningham, K. (Eds.) (2010). Integrating study abroad into the curriculum. Theory and practice across the disciplines. Sterling, VA: Stylus.

Brewer, E., \& Leask, B. (2012). Internationalization of the curriculum. In D. K. Deardorff, H. de Wit, J. D. Heyel, \& T. Adams (Eds.), The SAGE handbook of international higher education (pp. 245-266). Thousand Oaks, CA: SAGE.

Bucholtz, M., \& Hall, K. (2005). Identity and interaction: A sociocultural linguistic approach. Discourse Studies, 7(4-5), 585-614.

Busch, D. (2016). What is intercultural sustainability? A first exploration of linkages between culture and sustainability in intercultural research. Journal of Sustainable Development, 9(1), 63-76.

Canagarajah, S. (2011). Codemeshing in academic writing: Identifying teachable strategies of translanguaging. Modern Language Journal, 95(3), 401-417.

Case, K. A. (2007). Raising White privilege awareness and reducing racial prejudice: Assessing diversity course effectiveness. Teaching of Psychology, 34(4), 231-235. https://doi.org/10.1080/00986280701700250

Chen, R. T-H., \& Bennett, S. (2012). When Chinese learners meet constructivist pedagogy online. Higher Education, 64(5), 677-691. https://doi.org/10.1007/s10734-012-9520-9

Cho, S., Crenshaw, K. W., \& McCall, L. (2013). Toward a field of intersectionality studies: Theory, applications, and praxis. Signs, 38(4), 785-810. https://doi.org/10.1086/669608

Cole, D., \& Zhou, J. (2014). Diversity and collegiate experiences affecting selfperceived gains in critical thinking: Which works, and who benefits? The Journal of General Education, 63(1), 15-34. 
Connell, R. (2007). Southern theory: Social Science and the global dynamics of knowledge. Sydney: Allen \& Unwin.

Connell, R., Collyer, F., Maia, J., Morrell, R. (2016). Toward a global sociology of knowledge: Post-colonial realities and intellectual practices.

International Sociology, 32(1), 21-37.

http://dx.doi.org/10.1177/0268580916676913

Coulby, D. (2006). Intercultural education: Theory and practice. Intercultural Education, 17(3), 245-257.

Deardorff, D., De Wit, H., \& Heyel, H. J. (2012). Bridges to the future: The global landscape of international higher education. In D. K. Deardorff, H. de Wit, H. J. Heyel, \& T. Adams (Eds.). The SAGE handbook of international higher education, (pp. 457-486). Thousand Oaks, CA: SAGE Publications.

Denson, N., \& Bowman, N. (2013). University diversity and preparation for a global society: The role of diversity in shaping intergroup attitudes and civic outcomes. Studies in Higher Education, 38(4), 555-570.

Dervin, F. (2015). Towards post-intercultural teacher education: Analysing 'extreme' intercultural dialogue to reconstruct interculturality. European Journal of Teacher Education, 38(1), 71-86.

Dervin, F., \& Gross, Z. (2016). Introduction: Towards the simultaneity of intercultural competence. In F. Dervin \& Z. Gross, (Eds.) Intercultural competence in education. Alternative approaches for different times (pp. 110). London: Palgrave Macmillan.

de Sousa Santos, B. (2007). Beyond abyssal thinking: From global lines to ecologies of knowledges. Eurozine.

Doherty, C., \& Singh, P. (2005). How the West is done: Simulating western pedagogy in a curriculum for Asian international students. In P. Ninnes \& M. Hellsten (Eds.), Internationalizing higher education: Critical explorations of pedagogy and policy (pp. 53-73). Hong Kong: Comparative Education Research Centre, University of Hong Kong.

Edwards, J. (2006). Foundations of bilingualism. In T. K. Bhatia \& W. C. Ritchie (Eds.), The handbook of bilingualism (pp. 7-31). Oxford: Blackwell.

Enders, J. (2004). Higher education, internationalisation, and the nation-state: Recent developments and challenges to governance theory. Higher Education, 47, 361-382.

https://doi.org/10.1023/B:HIGH.0000016461.98676.30

Evans, S., \& Morrison, B. (2011). The student experience of English-medium higher education in Hong Kong. Language and Education, 25(1), 147-162.

Fahey, J. C., \& Kenway, J. (Eds). (2006). Globalizing the research imagination. Abingdon, UK: Routledge. 
Ferber, A., Herrera, A., Samuels, S. (2007). The matrix of oppression and privilege. American Behavioral Scientist, 51(4), 516-531.

Formby, E. (2017). How should we 'care' for LGBT+ students within higher education? Pastoral care in education: An international journal of personal, social and emotional development, 35(3), 203-220.

Fozdar, F., \& Volet, S. (2016). Cultural self-identification and orientations to crosscultural mixing on an Australian university campus. Journal of Intercultural Studies, 37(1), 51-68.

Gilardi, S., \& Guglielmetti, C. (2011). University life of non-traditional students: Engagement styles and impact on attrition. The Journal of Higher Education, 82(1), 33-52. https://doi.org/10.1080/00221546.2011.11779084

Goldberg, M. (2001). Arts and learning: An integrated approach to teaching and learning in multicultural and multilingual settings (2nd ed.). New York: Addison Wesley Longman.

Gorski, P. C. (2008). Good intentions are not enough: A decolonizing intercultural education. Intercultural education, 19(6), 515-525.

Graeber, D. (2011). Debt. The first 5000 years. Brooklyn, NY: Melville House.

Guo, Y., \& Guo, S. (2017). Internationalization of Canadian higher education: Discrepancies between policies and international student experiences. Studies in Higher Education, 42(5), 851-868.

https://doi.org/10.1080/03075079.2017.1293874

Haapakoski, J. (2020). Market exclusions and false inclusions. Mapping obstacles for more ethical approaches in the internationalization of higher education. Doctoral dissertation. University of Oulu.

Harvey, L., McCormick, B., \& Vanden, K. (2019). Becoming at the boundaries of language: Dramatic enquiry for intercultural learning in UK higher education. Language and Intercultural Communication, 19(6), 451-470. https://doi.org/10.1080/14708477.2019.1586912

Hoskins, B., \& Sallah, M. (2011). Developing intercultural competence in Europe: The challenges. Language and Intercultural Communication, 11(2), 113125.

Iverson, S. V. (2007). Camouflaging power and privilege: A critical race analysis of university diversity policies. Educational Administration Quarterly, 43(5), 586-611. https://doi.org/10.1177/0013161X07307794

Johnson, R. B., \& Onwuegbuzie, A. J. (2004). Mixed methods research: A research paradigm whose time has come. Educational Researcher, 33(7), 14-26.

Jokikokko, K. (2016). Reframing teachers' intercultural learning as an emotional process. Intercultural Education, 27(3), 217-230.

https://doi.org/10.1080/14675986.2016.1150648 
Jokikokko, K., \& Uitto, M. (2017). The significance of emotions in Finnish teachers' stories about their intercultural learning. Pedagogy, Culture and Society, 25(1), 15-29. https://doi.org/10.1080/14681366.2016.1201128

Kazuhiro, K., Volet, S., \& Whitsed, C. (2019). Development of intercultural relationships at university: a three-stage ecological and person-in-context conceptual framework. Higher Education, 77, 473-489.

King Choi, P. (2010). 'Weep for Chinese university': A case study of English hegemony and academic capitalism in higher education in Hong Kong. Journal of Education Policy, 25(2), 233-252.

Knight, J. (2011). Five myths about internationalization. International Higher Education, 62. https://doi.org/10.6017/ihe.2011.62.8532

Knight, J. (2014). Is internationalisation of higher education having an identity crisis? In A. Maldonado-Maldonado \& R. M. Bassett (Eds.), The forefront of international higher education (pp. 75-87). New York, NY: Springer.

Lazin, F., \& Evans, M., \& Jayaram, N. (2010). Higher education and equality of opportunities. Studies in public policy. Lanham, Md: Lexington Books.

Leask, B. (2009). Using formal and informal curricula to improve interactions between home and international students. Journal of Studies in International Education, 13, (2), 205-221

Liddicoat, A. J., Papademetre, L., Scarino, A., \& Kohler, M. (2003). Report on intercultural language learning. Canberra ACT: Commonwealth of Australia.

Lave, J., \& Wenger, E. (1991). Situated learning: Legitimate peripheral participation. Cambridge University Press.

https://doi.org/10.1017/CBO9780511815355

Long, A. (2016). Overcoming educational racism in the community college. VA, US: Stylus Publishing.

Mazak, C. M. (2017). Introduction: Theorising translanguaging practices in higher education. In C. M. Mazak \& K. S. Carroll (Eds.), Translanguaging in higher education: Beyond monolingual ideologies. Bristol, UK: Multilingual Matters.

McKinley, J., Dunworth, K., Grimshaw, T., \& Iwaniec, J. (2019). Developing intercultural competence in a 'comfortable' third space: Postgraduate studies in the UK. Language and Intercultural Communication, 19(1), 114. https://doi.org/10.1080/14708477.2018.1545028

Müller, J., Castaño, C., González, A., \& Palmén, R. (2011), Policy towards gender equality in science and research. Brussels Economic Review, 54(2/3), 295316. 
Nichols, S., \& Stahl, G. (2019). Intersectionality in higher education research: A systematic literature review. Higher Education Research and Development, 38(6), 1255-1268.

Nieto, S. (2000). Affirming diversity: The socio-political context of multicultural education (3rd ed.). New York, NY: Longman.

Nieto, S. (2017). Language, culture and teaching. Critical perspectives $\left(^{\text {rd }}\right.$ ed.). New York, NY: Routledge.

Owens, A. (2011). Supporting and evaluating transitional learning for international university students. Australian Universities Review, 53(1), 42-49.

Peterson, P. (2000). The worthy goal of a world faculty. Peer Review, 3(1), 3-7.

Pettigrew, T., \& Tropp, L. (2008). How does intergroup contact reduce prejudice? Meta-analytic tests of three mediators. European Journal of Social Psychology, 38(6), 922-934. https://doi.org/10.1002/ejsp.504

Prechtl, E., \& Davidson Lund, A. (2007). Intercultural competence and assessment: Perspectives from the INCA project. In H. Kotthoff \& H. Spences-Oatey (Eds.), Handbook of intercultural communication (pp. 467-490). Berlin: Mouton de Gruyter.

Preece, S. \& Martin, P. (2010). Imagining higher education as a multilingual space. Language and Education, 24(1), 3-8.

Rees, W. (2014). The Way Forward: Survival 2100. In Costanza, R. \& Kubiszewski, I. (Eds.), Creating a sustainable and desirable future (pp. 191-200) London: World Scientific.

Renfors, S. M. (2019). Internationalization of the curriculum in Finnish higher education: Understanding lecturers' experiences. Journal of Studies in International Education, 1-17. http://dx.doi.org/10.1177/1028315319888464

Rienties, B., Beausaert, S., Grohnert, T., Niemantsverdriet, S., \& Kommers, P. (2012). Understanding academic performance of international students: The role of ethnicity, academic and social integration. Higher Education, 63, $685-700$.

Ryan, J., (Ed.). (2013). Cross-cultural learning and teaching for home and international students. London: Routledge.

Räsänen, R. (2007). International education as an ethical issue. In M. Hayden, J. Levy, \& J. Thompson (Eds.), The SAGE handbook of research in international education (pp. 57-69). London: SAGE.

Räsänen, R., Jokikokko, K., \& Lampinen, J. (2018). Kultuuriseen moninaisuuteen liittyvä osaaminen perusopetuksessa. Kartoitus tutkimuksesta sekä opetushenkilöstön koulutuksesta ja osaamisen tuesta [Analysis of the development of competence related to cultural diversity from the viewpoint of basic education]. Opetushallitus: Raportit ja selvitykset 2018:6. 
Sawir, E., Marginson, S., Deumert, A., Nyland, C., \& Ramia, G. (2008). Loneliness and international students: An Australian study. Journal of Studies in International Education, 12(2), 148-180.

Schiebinger, L. (Ed.) (2008). Gendered innovations in science and engineering. Standford, CA: Stanford University Press.

Skutnabb-Kangas, T., Phillipson, R., Panda, M., \& Mohanty, A. (2009). MLE concepts, goals, needs and expense: English for all or achieving justice? In A. Mohanty, M. Panda, R. Phillipson, \& T. Skutnabb-Kangas, (Eds.) Multilingual education for social justice: Globalising the local (pp. 313334). New Delhi: Orient Blackswan.

Smit, R. (2012). Towards a clearer understanding of student disadvantage in higher education: Problematising deficit thinking. Higher Education Research \& Development, 31(3), 369-380. https://doi.org/10.1080/07294360.2011.634383

Spencer-Oatey, H., \& Dauber, D. (2019). Internationalisation and student diversity: How far are the opportunity benefits being perceived and exploited? Higher Education 78, 1035-1058.

Sperduti, V. (2017). Internationalization as westernization in higher education. Comparative \& International Education 9, 9-12. https://www.ojed.org/index.php/jcihe/article/view/887

Stevenson, J. (2012). Black and minority ethnic student degree retention and attainment. York: Higher Education Academy.

Sullivan, S. (2014). Good white people: The problem with middle-class white antiracism. Albany, New York: State University of New York Press.

Takayama, K., Heimans, S., Amazan, R., \& Maniam, V. (2016). Doing southern theory: Towards alternative knowledges and knowledge practices in/for education. Postcolonial Directions in Education, 5(1), 1-25.

Taylor, L. (2011). Beyond paternalism: Global education with preservice teachers as a practice of implication. In V. Andreotti \& L. M. T. M. de Sousa (Eds.), Postcolonial perspectives on global citizenship education (pp. 177-199). New York: Routledge.

Tereskinas, A. (2010). Limited sexual citizenship in Lithueinia. In E. Reimers \& L. Martinson (Eds.), Norm-struggles. Sexualities in contentions (pp. 142-159). City of publication? UK: Cambrige.

Turner, Y. (2009). Knowing me, knowing you. Is there nothing we can do? Pedagogic challenges in using group work to create an intercultural learning space. Journal of Studies in International Education, 13(2), 240-255.

Turner, C. S. (2013). Advancing diversity in higher education. Journal of Diversity in Higher Education, 6(3), 155-157. 
van der Walt, C. (2013). Multilingual higher education. Beyond English medium orientations. Multilingual Matters.

van Gaalen, A. (Ed.). (2010). Internationalisation and quality assurance. Amsterdam: Netherlands: EAIE: European Association of International Educators.

Vasquez, G. (2005). Nurturance in the Andes. In C. A. Bowers \& F. Apffel-Marglin (Eds.), Rethinking Freire: Globalization and the environmental crisis (pp. 31-47). London: Lawrence Erlbaum Associates

Whitchurch, C. (2008). Shifting identities and blurring boundaries: The emergence of third space professionals in UK higher education. Higher Education Quarterly, 62(4), 377-396.

Winston, R. P. (2001). Discipline and interdiscipline: Approaches to study abroad. Frontiers: The Interdisciplinary Journal of Study Abroad, 6, 61-93.

Woodruff, G., Martin, K., \& O’ Brien, K. (2015). Internationalising teaching and learning: Transforming teachers, transforming students. In R. D. Williams \& A. Lee (Eds.), Internationalizing higher education: Critical collaborations across the curriculum (pp. 63-96). Netherlands: Sense.

Young, T., Handford, M., \& Schartner, A. (2017). The internationalising university: An intercultural endeavour? Journal of Multilingual and Multicultural Development, 38(3), 189-191.

Zembylas, M. (2012). Manifestations of Greek-Cypriot teachers' discomfort towards a peace education initiative: Engaging with discomfort pedagogically. Teaching and Teacher Education 28(8), 1071-1082.

Zembylas, M., \& McGlynn, C. (2012). Discomforting pedagogies: emotional tensions, ethical dilemmas and transformative possibilities. British Educational Research Journal, 38(1), 49-59. 